\title{
黄土高原水土保持生态建设耗水量宏观分析*
}

\author{
崔 庆 1 徐建华 2 单 伟 1 \\ （1:黄河水利委员会信息中心,郑州 450004; 2: 黄河水利委员会水文局，郑州 450004 )
}

提 要 黄土高原水土保持现状减水约 10 亿 $\mathrm{m}^{3}$, 但大规模综合治理后耗水量是多少? 本 文通过多种方法分析，2010 年、2030 年和 2050 年水土保持生态建设需耗水约 20 亿 $\mathrm{m}^{3}, 40$ 亿 $\mathrm{m}^{3}$ 和 50 亿 $\mathrm{m}^{3}$.

关键词 水土保持 生态建设 耗水量 黄土高原

分类号

黄土高原水土流失严重，经过几十年的综合治理，水利水保工程现状减少入黄泥沙约 $3 \times 10^{8} \mathrm{t}$, 减少入黄水量约 $10 \times 10^{8} \mathrm{~m}^{3}$. 但大规模综合治理后, 将耗水多少? 这是黄河水资源 规划中必须回答的问题. 本文综合各种方法, 从不同角度加以分析.

\section{1 按径流组成分析}

该方法的基本思路认为 ${ }^{* *}$, 水土保持措施只能影响地表径流，对地下径流基本没影响. 在“黄河的重大问题及对策”分析中，认为河口镇以上耗水主要是水利工程，水土保持耗水 很少，可不作分析. 而河口镇至花园口区间的 $24.4 \times 10^{4} \mathrm{~km}^{2}$ 水土流失区又分为多沙粗沙区 和一般流失区. 多沙粗沙区主要包括河口镇至龙门，泾河亭口站以上，北洛河交口站以上 和渭河南河川站以上，流域面积 $18.68 \times 10^{4} \mathrm{~km}^{2}$ ，与过去规划中常说的多沙粗沙区面积 19.1 $\times 10^{4} \mathrm{~km}^{2}$ (实际是多沙区) 差不多. 其它为一般流失区，面积 $5.3 \times 10^{4} \mathrm{~km}^{2}$.

\section{1 多沙粗沙区减水量分析}

在多沙粗沙区，天然情况下多年平均年径流量 $103 \times 10^{8} \mathrm{~m}^{3}$ ( 1949 年 7 月到 1961 年 6 月 ), 其中基流 $53.1 \times 10^{8} \mathrm{~m}^{3}$, 汛期地表径流为 $49.9 \times 10^{8} \mathrm{~m}^{3}$. 由此推算过去规划中常用的多 沙粗沙区 $\left(19.1 \times 10^{4} \mathrm{~km}^{2}\right)$ 汛期地表径流为 $51 \times 10^{8} \mathrm{~m}^{3}$.

各种水土保持措施利用地表径流量的最大数量，是指 2050 年达到较高水平条件下的 径流利用率. 在较高水平条件下，治理有效面积按流失面积的 $90 \%$ 计，有效面积的径流利 用率按规划的措施构成比例及利用径流率加权平均计算，其值为 $70 \%$ ，二者相乘就是该区

\footnotetext{
* 2003-08-08 收稿,2004-09-17 收修改稿. 崔庆,女,1962 年生,高级工程师. Email : cuiqing@yrcccab.com

** “黄河的重大问题及对策”研究组,黄河流域黄土高原水土保持措施利用径流量的宏观分析,1999
} 
的径流利用率为 $63 \%$.

由上分析，水土保持措施实施后，在较高治理水平条件下，最大用水率按 $63 \%$ 计，共 用水量 $32.1 \times 10^{8} \mathrm{~m}^{3}$.

\section{2 一般流失区减水量分析}

在一般流失区，由于实测径流资料受渭、汾平原及干流大中型水库及灌区影响很大， 难以分割出地下径流与地表径流. 依据上述, 多沙粗沙区实测的汛期地表径流模数为 2.67 $\times 10^{4} \mathrm{~m}^{3} / \mathrm{km}^{2}$ ，考虑到一般流失区处于多沙粗沙区的南面，降水量偏大，其汛期地表径流模 数采用 $3 \times 10^{4} \mathrm{~m}^{3} / \mathrm{km}^{2}$ 分析计算较为合理. 据此, 一般流失区的汛期地表径流量为 $15.9 \times$ $10^{8} \mathrm{~m}^{3}$. 水土保持措施实施后，较高治理水平条件下，最大用水率仍按 $63 \%$ 计，其用水量 为 $10 \times 10^{8} \mathrm{~m}^{3}$.

\section{3 河口镇至花园口区间减水量分析}

河口镇-花园口区间，流域面积 $34.4 \times 10^{4} \mathrm{~km}^{2}$ ，水土流失面积 $24.4 \times 10^{4} \mathrm{~km}^{2}$, 占流域总 面积的 $70 \%$ ，地表径流总量为 $66.9 \times 10^{8} \mathrm{~m}^{3}$ ，较高治理水平条件下，最大用水量为 $42.1 \times$ $10^{8} \mathrm{~m}^{3}$ ( 不含回归因素 ).

该研究对各水平年用水推荐框算 (均以概略数计 ) 结果如下:

(1) 现状 (1998 年) 水平达 $(8-10) \times 10^{8} \mathrm{~m}^{3}$;

（２） 2010 年水平达 $15 \times 10^{8} \mathrm{~m}^{3}$ 左右;

（３） 2030 年水平达 $30 \times 10^{8} \mathrm{~m}^{3}$ 左右;

（４）２050 年较高标准水平达到 $40 \times 10^{8} \mathrm{~m}^{3}$ 左右.

\section{2 按水土保持规划措施预估}

该方法的基本思路是根据各规划水平年的水土保持措施量与各项措施减水指标综合 分析得来, 由于各家的减水指标和措施规划指标的不同, 结果也不一样, 现介绍如下.

\section{1 按水土保持规划措施分析(I) (1)}

黄委会水科院在“黄河流域防洪规划”项目中，进行了“黄河中游水土保持减水减沙作用 分析”，该报告参照“八五”攻关研究成果，提出各项措施平水年减水指标是：梯条田 296 $\mathrm{m}^{3} / \mathrm{hm}^{2}$ 、林地 $248 \mathrm{~m}^{3} / \mathrm{hm}^{2}$ 、草地 $210 \mathrm{~m}^{3} / \mathrm{hm}^{2}$ 、水地 $296 \mathrm{~m}^{3} / \mathrm{hm}^{2}$ 和坝地 $4500 \mathrm{~m}^{3} / \mathrm{hm}^{2}$, 再 参照 1997 年编制的《黄河流域黄土高原地区水土保持建设规划》提出的规划指标分析水 土保持措施耗水量结果为：

规划基准年: 减水量 $8 \times 10^{8}-10 \times 10^{8} \mathrm{~m}^{3}$.

2010 年: 减水量 $14 \times 10^{8}-18 \times 10^{8} \mathrm{~m}^{3}$.

2020 年: 减水量 $25 \times 10^{8}-30 \times 10^{8} \mathrm{~m}^{3}$.

\section{2 按水土保持规划措施分析(II) ${ }^{[1]}$}

根据《全国水土保持建设规划》中提出 2001-2050 年黄土高原将新增基本农田 1245 $\times 10^{4} \mathrm{hm}^{2}$ ，骨干坝 2 万座 (淤地 $20 \times 10^{4} \mathrm{hm}^{2}$ )，林草地 $2965 \times 10^{4} \mathrm{hm}^{2}$ 的规划目标，再根据 各种措施减水指标，林草 $10 \%$ 即 $75 \mathrm{~m}^{3} / \mathrm{hm}^{2}$ ) 水平梯田 $50 \%\left(300 \mathrm{~m}^{3} / \mathrm{hm}^{2}\right.$ )和坝地 $300 \mathrm{~m}^{3} / \mathrm{hm}^{2}$ 计算，到 2050 年林草减少径流量 $22.23 \times 10^{8} \mathrm{~m}^{3}$ ，水平梯田拦蓄径流量 $37.4 \times 10^{8} \mathrm{~m}^{3}$ ，坝地 
年拦蓄 $0.6 \times 10^{8} \mathrm{~m}^{3}$, 总减水至少 $60 \times 10^{8} \mathrm{~m}^{3}$.

2.3 按水土保持规划措施分析(III)

根据水利部黄河水沙变化研究基金第二期苒大川分析的河龙镇至龙门区间各种水土 保持措施耗水量[2]，计算出单项措施耗水比值，梯田( $\left.78 \mathrm{~m}^{3} /\left(\mathrm{hm}^{2} \cdot \mathrm{a}\right)\right)>$ 造林 $\left(31 \mathrm{~m}^{3} /\left(\mathrm{hm}^{2} \cdot \mathrm{a}\right)\right)>$ 种草 $\left(20 \mathrm{~m}^{3} /\left(\mathrm{hm}^{2} \cdot \mathrm{a}\right)\right)$. 再根据《黄河近期重点治理开发规划》[3]确定的 2010 年和水保规 划资料确定的 2030 年规划的坡面措施量(2，估算出 2010 年和 2030 年水保措施耗水量为 $16.1 \times 10^{8} \mathrm{~m}^{3}$ 和 $41 \times 10^{8} \mathrm{~m}^{3}$ ( 见表 1 )。

表 1 水土保持措施耗水估算表

Tab. 1 Estimate for consumed amount of water by the conservation of soil and water

\begin{tabular}{|c|c|c|c|c|c|c|c|}
\hline 时段 & 分类 & 梯田 & 造林 & 种草 & 坝地 & 合计 & 资料来源 \\
\hline 1970-1996 & $\begin{array}{c}\text { 水保措施保存量 } \\
\left(10^{4} \mathrm{hm}^{2}\right)\end{array}$ & 30.08 & 143.98 & 13.95 & 4.18 & & [4] \\
\hline ( 河龙区 & 措施减水量 $\left(10^{4} \mathrm{~m}^{3} / \mathrm{a}\right)$ & 2355 & 4429 & 275 & 7559 & & [4] \\
\hline 间） & $\begin{array}{c}\text { 单位面积耗水量 } \\
\left(\mathrm{m}^{3} / \mathrm{hm}^{2} \cdot \mathrm{a}\right)\end{array}$ & 78.29 & 30.76 & 19.71 & & & \\
\hline 2010 年 & 措施量 $\left(10^{4} \mathrm{hm}^{2}\right)$ & 847.81 & 1567.13 & 157.45 & & & [5] \\
\hline (全河) & 耗水量 $\left(10^{8} \mathrm{~m}^{3} / \mathrm{a}\right)$ & 6.6375 & 4.8207 & 0.31 & 4.3 & 16.07 & \\
\hline 2030 年 & 措施量 $\left(10^{4} \mathrm{hm}^{2}\right)$ & 1203.82 & 2389.73 & 399.45 & & & (2) \\
\hline (全河) & 耗水量 $\left(10^{8} \mathrm{~m}^{3} / \mathrm{a}\right)$ & 9.4247 & 7.3508 & 0.79 & 23.1 & 40.67 & \\
\hline
\end{tabular}

表中未来淤地坝耗水量是依据“黄河流域黄土高原地区水土保持淤地坝建设规划”中的 淤地坝建设进度，根据淤地坝的运行方式，考虑了淤地坝地种植后的耗水量、骨干坝淤满 前的水面蒸发损失量、人畜饮水、生态用水以及灌溉用水等计算得来 (3. 经分析 2010 年坝 地耗水 $4.3 \times 10^{8} \mathrm{~m}^{3}, 2020$ 年 $16.8 \times 10^{8} \mathrm{~m}^{3}, 2030$ 年 $23.1 \times 10^{8} \mathrm{~m}^{3}, 2040$ 年 $25.4 \times 10^{8} \mathrm{~m}^{3}$.

\section{3 按减沙目标分析}

根据作者在国家自然科学基金委员会重大项目“黄河流域环境演变与水沙运行规律研 究”中第二课题“流域侵蚀产沙规律及水利水保效益分析”报告®: 1970-1989 年，黄河上中 游水利水保工程共拦泥 $5.52 \times 10^{8} \mathrm{t}$ ，其中水库拦泥 $2.17 \times 10^{8} \mathrm{t}$ ，灌溉引沙 $0.64 \times 10^{8} \mathrm{t}$ ，水土 保持拦泥 $2.71 \times 10^{8}$ t. 根据“黄河的重大问题及对策”分析，水土保持现状耗水约 $10 \times 10^{8} \mathrm{~m}^{3}$, 该报告提出: 2010 年, 2030 年和 2050 年减少入黄泥沙目标分别为 $5 \times 108 \mathrm{t}, 6 \times 10^{8} \mathrm{t}$ 和 8 $\times 108 \mathrm{t}$ 左右 ${ }^{5}$.

由现状看出，拦泥 $5.52 \times 10^{8}$ t，减少入黄泥沙 $3 \times 10^{8}$ t. 若要水土保持减少入黄泥沙 $5 \times$

(2)水利部黄河水利委员会,黄河流域黄土高原地区水土保持建设规划,1997.11

(3)水利部黄河水利委员会,黄河流域黄土高原地区水土保持淤地坝建设规划,2003.5

(4)徐建华,黄河中上游水利水保措施的减沙作用分析.1992.4

(5)中华人民共和国水利部，黄河的重大问题及对策.1999.10 
$10^{8 \mathrm{t}}, 6 \times 10^{8 \mathrm{t}}$ 和 $8 \times 10^{8} \mathrm{t}$ ，相应拦沙为 $9.2 \times 10^{8} \mathrm{t} ， 11.04 \times 10^{8} \mathrm{t}$ 和 $14.72 \times 10^{8} \mathrm{t}$. 现状水土保持 措施拦沙 $2.71 \times 10^{8} \mathrm{t}$ 时，耗水 $10 \times 10^{8} \mathrm{~m}^{3}$ ，拦沙 $9.2 \times 10^{8} \mathrm{t}, 11.04 \times 10^{8} \mathrm{t}$ 和 $12.88 \times 10^{8} \mathrm{t}$ 相应 耗水量为 $34 \times 10^{8} \mathrm{~m}^{3}, 41 \times 10^{8} \mathrm{~m}^{3}$ 和 $54 \times 10^{8} \mathrm{~m}^{3}$.

\title{
4 综合分析
}

经过多种方法的综合分析 (表 2 ), 大致按照算术平均法估算黄土高原不同时期的水土 保持耗水情况是: 现状耗水约 $10 \times 10^{8} \mathrm{~m}^{3}, 2010$ 年耗水约 $20 \times 10^{8} \mathrm{~m}^{3}, 2030$ 年约 $40 \times 10^{8} \mathrm{~m}^{3}$ 到 2050 年将达 $50 \times 10^{8} \mathrm{~m}^{3}$. 由上看出，在黄河水资源规划中，对生态环境建设用水要有充 分估计，才能保证黄河生态用水的安全.

\section{表 2 黄土高原水土保持生态建设需水量宏观分析汇总}

Tab. 2 Required water amount by ecology construction of the conservation of water and soil in Loess Plateau

\begin{tabular}{|c|c|c|c|c|c|c|c|c|}
\hline \multirow{2}{*}{$\begin{array}{l}\text { 编 } \\
\text { 号 }\end{array}$} & \multirow{2}{*}{ 分析方法 } & \multirow{2}{*}{$\begin{array}{c}\text { 时间 } \\
\text { (年.月) }\end{array}$} & \multicolumn{5}{|c|}{ 各水平年减水量 $\left(\right.$ 亿 $\left.\mathrm{m}^{3}\right)$} & \multirow{2}{*}{$\begin{array}{l}\text { 资源 } \\
\text { 来源 }\end{array}$} \\
\hline & & & 现状 & 2010 & 2020 & 2030 & 2050 & \\
\hline 1 & 按径流组成分析 & 1999 & $8-10$ & 15 & & 30 & 40 & [1] \\
\hline 2 & 按水土保持措施规划分析 & 1999.5 & $8-10$ & $14-18$ & $25-30$ & & & [2] \\
\hline 3 & 按水土保持措施规划分析 & 2002.1 & & & & & 60 & [3] \\
\hline 4 & 按水土保持措施规划分析 & & & 16 & & 41 & & \\
\hline 5 & 按规划减沙目标分析 & & 10 & 34 & & 41 & 54 & \\
\hline 6 & 推荐意见 & & 10 & 20 & 30 & 40 & 50 & \\
\hline
\end{tabular}

参 考 文 献

1 景可,申元村.黄河中游黄土高原水土保持对未来地表水资源影响研究,中国水土保持,2002,(1)

2 再大川,柳林旺,赵力仪等.黄河中游河口镇至龙门区间水土保持与水沙变化,郑州:黄河水利出版社,2000.5

3 水利部黄河水利委员会编著,黄河近期重点治理开发规划.郑州:黄河水利出版社,2002.11

\section{The Water Consumption Analysis of Ecological Construction of Soil and Water Conservation in Loess Plateau}

\author{
CUI Qing ${ }^{1}, \quad$ XU Jianhua ${ }^{2} \&$ SHAN Wei ${ }^{1}$ \\ (1:Information Center, YRCC, Zhengzhou 450004, P.R.China; 2: Hydrology Bureau, YRCC, Zhengzhou 450004, P.R.China)
}

\begin{abstract}
The actual runoff reduction of soil and water conservation in Loess plateau is about 1.0 billion $\mathrm{m}^{3}$. How many would be the water consumption after large-scale harness? It is pointed out that the number is about 2.0 billion $\mathrm{m}^{3}, 4.0$ billion $\mathrm{m}^{3}$ and 5.0 billion $\mathrm{m}^{3}$, respectively in 2010,2020 and 2050, through multi-method analysis.
\end{abstract}

Keywords: Soil and water conservation; ecological construction; water-demand; Loess Plateau 